\title{
PENGARUH PENGELUARAN KESEHATAN DAN PENDIDIKAN SERTA INFRASTRUKTUR TERHADAP INDEKS PEMBANGUNAN MANUSIA DI PROVINSI MALUKU
}

\author{
Oleh : \\ Abdul Kadir Mahulauw \\ Dwi Budi Santosa \\ Putu Mahardika \\ Program Magister Ilmu Ekonomi Pascasarjana - \\ Fakultas Ekonomi Dan BisnisUniversitas Brawijaya
}

\begin{abstract}
The purpose of research is to see how the effect of government spending on education, health, and infrastructure to increase HDI District / City in Maluku Province. The research method using path analysis (path analysis) with the test criteria at the level of 5\% error to view the Maluku provincial government spending on education, health, infrastructure, and also the income per capita as an intervening variable. Results of the analysis showed that the simultaneous three types of government spending such a significant effect on the HDI. It was found that with $R$ Square of $68.1 \%$ and $31.9 \%$ explained by other variables outside the model and the partial income per capita as an intervening variable no significant effect on the increase in the HDI.
\end{abstract}

Keywords: Education, Health, Infrastructure, Per Capita Income, HDI

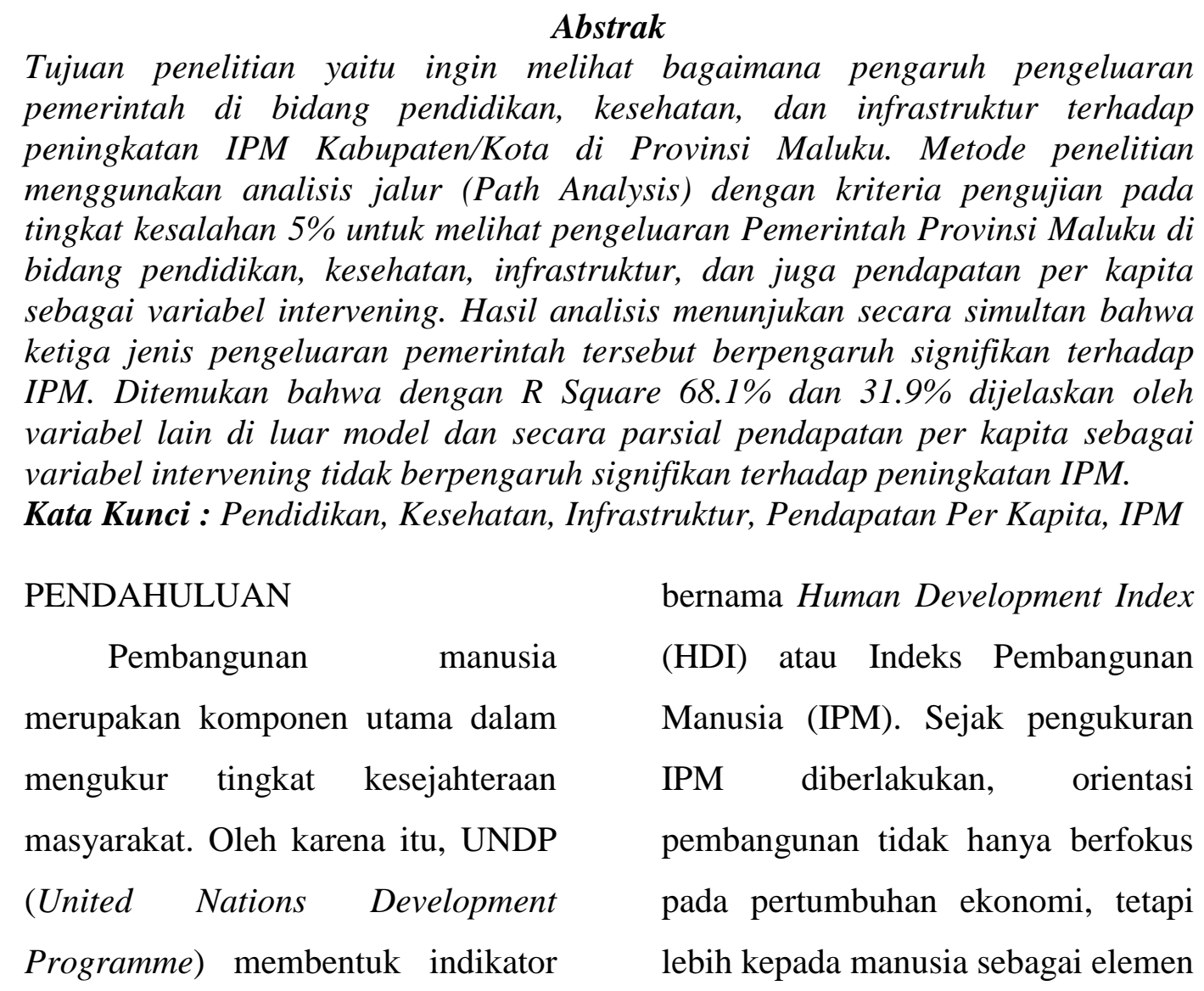


dasar untuk mencapai pembangunan yang berkelanjutan (UNDP, 1990; Badrudin, 2011). Secara teknis, IPM memberikan suatu ukuran gabungan pada tiga dimensi, yaitu: (i) umur panjang dan hidup sehat (life expectancy at birth); (ii) pengetahuan (adult literacy rate) dan rata-rata lama sekolah penduduk dewasa (mean years schooling); serta (iii) standar hidup layak (purchasing power parity).

Upaya meningkatkan IPM di Indonesia dilakukan melalui instrumen kebijakan fiskal, dimana penyediaan pelayanan dasar dilaksanakan melalui mekanisme anggaran. Alokasi anggaran bidang kesehatan dan pendidikan masuk dalam kategori belanja sosiaL. Dalam praktiknya, pemerintah daerah mempunyai kebijakan yang berbeda dalam meningkatkan sumber daya manusianya. Hal ini dapat dilihat pada format penganggaran belanjanya pada bidang kesehatan dan pendidikan, sehingga hasil yang diperoleh tiap-tiap daerah berbedabeda. Kondisi demikian menjadi polemik yang memunculkan perdebatan peran pemerintah yang belum maksimal dalam mensejahterakan masyarakat melalui penerapan kebijakan IPM.

Pendalaman kasus pengeluaran pemerintah dan tingkat IPM sangat relevan dengan studi kasus di Provinsi Maluku. Maluku merupakan salah satu provinsi dengan tingkat pertumbuhan ekonomi yang tinggi, bahkan pernah di atas nasional (Panel A). Namun demikian, hasil pengukuran IPM Provinsi Maluku masih sangat rendah (Panel B). Pertumbuhan ekonomi Provinsi Maluku yang tinggi sangat kontradiktif dengan IPM Maluku yang selalu di bawah nasional. Data ini menggambarkan bahwa kinerja pembangunan manusia di Provinsi Maluku belum mencapai tingkat yang optimal. 


\section{Gambar 1. Pertumbuhan Ekonomi dan IPM Provinsi Maluku}

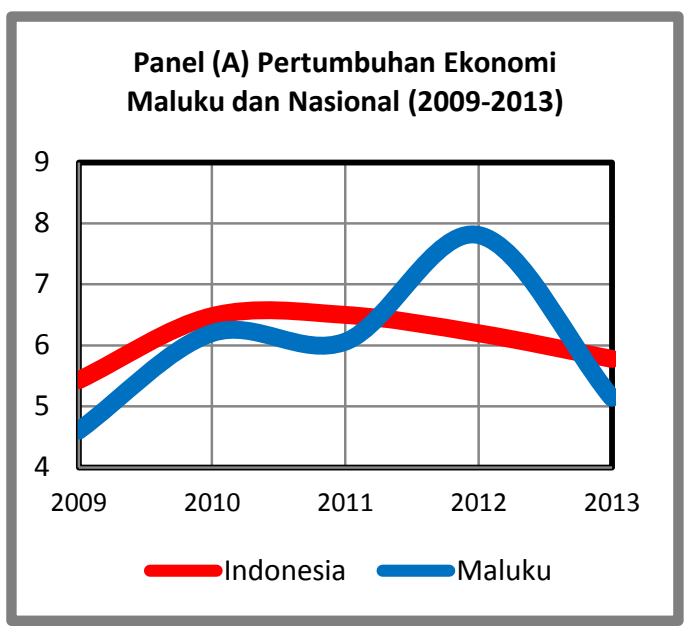

Sumber: BPS Maluku, 2013 (Diolah)

Padahal secara umum, total pengeluaran pemerintah di sektor pendidikan, kesehatan dan infrastruktur Kabupaten/Kota di Provinsi Maluku menunjukkan tren yang meningkat cukup signifikan setiap tahunnya (BPS Provinsi Maluku, 2013). Hal ini sebanding dengan tingkat pertumbuhan ekonomi Provinsi Maluku yang memang terus meningkat setiap tahunnya (kecuali tahun 2011).

Kasus ini menunjukkan bahwa masih adanya keraguan pengaruh antara pengeluaran pemerintah dan hasil pembangunan manusia yang diharapkan. Keterkaitan antara pengeluaran pemerintah yang tinggi

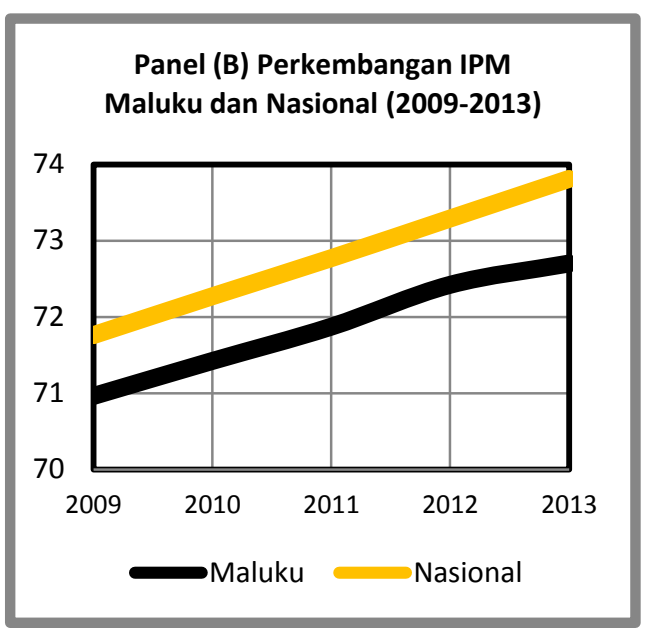

Sumber: BPS Maluku, 2013 (Diolah)

dan IPM yang belum optimal di Provinsi Maluku memberikan indikator perlunya melihat bagaimana hal ini bisa terjadi. Kondisi ketidaksinkronan antara pengeluaran pemerintah dan tingkat IPM di Provinsi Maluku dapat menjadi jawaban dan penjelas atas polemik antara pengaruh pengeluaran pemerintah dan tingkat IPM. Oleh karena itu, penelitian ini mencoba menjawab dan mengeksplorasi pengaruh pengeluaran pemerintah terhadap IPM di Provinsi Maluku melalui tiga tujuan, yaitu: (i) menganalisis pengaruh pengeluaran pemerintah di bidang pendidikan terhadap 
peningkatan IPM di Kabupaten/Kota Propinsi Maluku; (ii) menganalisis pengaruh pengeluaran pemerintah di bidang kesehatan terhadap peningkatan IPM di Kabupaten/Kota Propinsi Maluku; dan menganalisis pengaruh pengeluaran pemerintah di bidang infrastruktur terhadap peningkatan IPM di Kabupaten/ Kota Propinsi Maluku.

\section{METODE PENELITIAN}

Penelitian ini menggunakan data sekunder yang dikeluarkan oleh Badan Pusat Statistik (BPS) Provinsi Maluku, Bagian Keuangan Kabupaten Buru dan Bagian Keuangan Propinsi Maluku Direktorat Jenderal Perimbangan Keuangan (DJPK), dan Badan Pemeriksa Keuangan (BPK) dalam beberapa publikasi. Penelitian ini menggunakan pooled data (data panel), yaitu dengan menggabungkan data tahun 2009 - 2013 (T=5) atas 11 Kabupaten/kota di Maluku ( $\mathrm{N}=5$ ). Maka banyaknya data dalam penelitian adalah $\mathrm{N} \times \mathrm{T}=5 \times 11$ sama dengan 55 .

Data yang digunakan dalam penelitian ini adalah data sekunder yang diperoleh dari publikasi lembaga yang berwenang, bukubuku, literatur, internet, catatancatatan, serta sumber lain yang berhubungan dengan masalah penelitian. Adapun data yang dibutuhkan dalam penelitian ini antara lain: (i) data Indeks Pembangunan Manusia 11 Kabupaten/Kota di Maluku tahun 2009-2013; (ii) data realisasi pengeluaran pemerintah bidang pendidikan menurut fungsi 11 Kabupaten/Kota di Maluku tahun 2009-2013; (iii) data realisasi pengeluaran pemerintah bidang kesehatan menurut fungsi 11 Kabupaten/Kota di Maluku tahun 2009-2013; (iv) data realisasi pengeluaran pemerintah bidang infrastruktur jalan 11 Kabupaten/Kota di Maluku tahun 2009-2013; (v) data pendapatan perkapita 11 Kabupaten/Kota di Maluku tahun 2009-2013; dan (vi) data total realisasi APBD 11 Kabupaten/Kota di Maluku tahun 2009-2013.

Untuk menjawab rumusan masalah yang diangkat dalam penelitian ini, maka digunakan metode analisis jalur (Path Analysis). 
Melalui diagram jalur, secara garis besar sangat membantu untuk menggambarkan pola hubungan kausal antara sejumlah peubah, dan analisis jalur ini memiliki daya guna untuk mencetak atau menguji kausal yang diteorikan dan bukan untuk menurunkan teori kausal tersebut (Riduan\& Kuncoro, 2010).

Dalam metode analisis jalur ini, terdapat pengaruh langsung dan tidak langsung. Pengaruh langsung artinya arah hubungan antara dua variabel langsung tanpa melewati variabel lain, sementara pengaruh tidak langsung harus melewati variabel lain. Untuk melihat besarnya pengaruh langsung antar variabel dengan menggunakan koefisien beta atau koefisien regresi yang distandardisasi. Sedangkan besarnya pengaruh tidak langsung dalam path analysis adalah dengan cara mengalikan koefisien pengaruh langsung variable bebas terhadap variabel terikat.

Berdasarkan model hipotesis yang telah dibuat, maka dikonversi dalam bentuk persamaannya adalah sebagai berikut:
Persamaan sub struktur-1 :

merupakan pengaruh Kesehatan terhadap IPM

$$
X_{5}=p x 5 x 1 X_{1}+p x 5 e_{1}
$$

Persamaan sub struktur-2 :

merupakan pengaruh Pendidikan terhadap IPM

$$
X_{5}=p x 5 \times 2 X_{2}+p x 5 e_{2}
$$

Persamaan sub struktur-3 :

merupakan pengaruh infrastruktur terhadap IPM

$$
X_{5}=p x 5 \times 3 X_{3}+p x 5 e_{3}
$$

Persamaan sub PDRB Per kapita -4: merupakan pengaruh infrastruktur terhadap IPM

$$
X_{5}=p x 5 x 4 X_{4}+p x 5 e_{4}
$$

\section{PEMBAHASAN}

\section{Asumsi Normalitas}

Pada analisis path, data yang digunakan adalah data yang berdistribusi normal. Hipotesis yang digunakan dalam pengujian adalah sebagai berikut:

$\mathrm{H}_{0} \quad$ : Sebaran data berdistribusi normal

$\mathrm{H}_{\mathrm{a}} \quad$ : Sebaran data tidak berdistribusi normal

Untuk menguji asumsi ini, digunakan metode Kolmogorov- 
Smirnov. Kriteria pengujian yang terima $\mathrm{H}_{0}$ jika nilai signifikansi > digunakan adalah tolak $\mathrm{H}_{0}$ jika nilai 0,05 .

signifikansi $\leq 0,05$, dan sebaliknya

Tabel 1. Uji Normalitas

\begin{tabular}{cccc}
\hline Persamaan & Statistik Uji & Signifikansi & Keterangan \\
\hline Persamaan 1 & 0,087 & 0,200 & Menyebar Normal \\
\hline Persamaan 2 & 0,116 & 0,064 & Menyebar Normal
\end{tabular}

Sumber : Data primer diolah, 2016

Berdasarkan pengujian

Perhitungan koefisien path

Kolmogorov-Smirnov, pada masingmasing persamaan 1 dan 2 diperoleh signifikansi sebesar 0,200 dan 0,064, dimana nilai yang diperoleh lebih besar daripada $\alpha=0,05$. Oleh karena nilai signifikansi lebih besar daripada $\alpha=0,05$, maka diputuskan terima $\mathrm{H}_{0}$ dan disimpulkan bahwa data yang digunakan pada masing-masing persamaan berdistribusi normal, sehingga disimpulkan asumsi normalitas terpenuhi.

pada penelitian ini menggunakan analisis path dengan melihat pengaruh secara simultandan parsial pada masing-masing persamaan. Persamaan yang diperoleh dinyatakan dalam bentuk persamaan sebagai berikut:

$\mathrm{X}_{4}=\mathrm{P}_{\mathrm{X} 4 \mathrm{X} 1} \mathrm{X}_{1}+\mathrm{P}_{\mathrm{X} 4 \mathrm{X} 2} \mathrm{X}_{2}+\mathrm{P}_{\mathrm{X} 4 \mathrm{X} 3} \mathrm{X}_{3}$

\section{Analisis Path}

$+\varepsilon_{1}$

$\mathrm{Y}=\mathrm{P}_{\mathrm{YX} 1} \mathrm{X}_{1}+\mathrm{P}_{\mathrm{YX} 2} \mathrm{X}_{2}+\mathrm{P}_{\mathrm{YX} 3} \mathrm{X}_{3}+$ $\mathrm{P}_{\mathrm{YX} 4} \mathrm{X}_{4}+\varepsilon_{2}$

Pengaruh X1, X2, X3 terhadap X4 (Persamaan 1)

Tabel 2. Hasil Analisis Path X1, X2, X3 terhadap X4

\begin{tabular}{cccccc}
$\begin{array}{c}\text { Variabel } \\
\text { Dependen }\end{array}$ & $\begin{array}{c}\text { Variabel } \\
\text { Independen }\end{array}$ & Beta & t & Sig t & Keterangan \\
\hline $\mathbf{X 4}$ & $\mathrm{X} 1$ & 0,024 & 0,169 & 0,867 & $\begin{array}{c}\text { Tidak } \\
\text { Signifikan }\end{array}$ \\
\cline { 2 - 6 } & $\mathrm{X} 2$ & 0,003 & 0,019 & 0,985 & $\begin{array}{c}\text { Tidak } \\
\text { Signifikan }\end{array}$ \\
\cline { 2 - 6 } & $\mathrm{X} 3$ & 0,227 & 1,641 & 0,107 & $\begin{array}{c}\text { Tidak } \\
\text { Signifikan }\end{array}$ \\
\hline R Square & $=$ & 0,052 & & \\
\hline F hit & $=$ & 0,941 & & \\
\hline Signifikansi & $=$ & 0,428 & &
\end{tabular}

Sumber : Data primer diolah, 2016

Pengaruh X1, X2, X3, X4, terhadap Y (Persamaan 2) 
Tabel 3. Hasil Analisis Path Pengaruh X1, X2, X3, X4, terhadap Y

\begin{tabular}{cccccc}
\hline $\begin{array}{c}\text { Variabel } \\
\text { Dependen }\end{array}$ & $\begin{array}{c}\text { Variabel } \\
\text { Independen }\end{array}$ & Beta & $\mathrm{T}$ & Sig t & Keterangan \\
\hline $\mathbf{Y}$ & $\mathrm{X} 1$ & 0,291 & 3,552 & 0,001 & Signifikan \\
\cline { 2 - 6 } & $\mathrm{X} 2$ & 0,686 & 8,324 & 0,000 & Signifikan \\
\cline { 2 - 6 } & $\mathrm{X} 3$ & 0,232 & 2,791 & 0,007 & Signifikan \\
\cline { 2 - 6 } & $\mathrm{X} 4$ & 0,120 & 1,462 & 0,150 & Tidak Signifikan \\
\hline R Square & $=$ & 0,681 & & \\
\hline F hit & $=$ & 26,661 & & \\
\hline Signifikansi & $=$ & 0,000 & & \\
\hline
\end{tabular}

Sumber : Data primer diolah, 2016

Dari kedua persamaan

tersebut, diperoleh hasil analisis jalur

(path) secara keseluruhan adalah:

\section{Gambar 2. Hasil Analisis Path pada $X_{1}, X_{2}, X_{3}$ Terhadap Y melalui $X_{4}$}

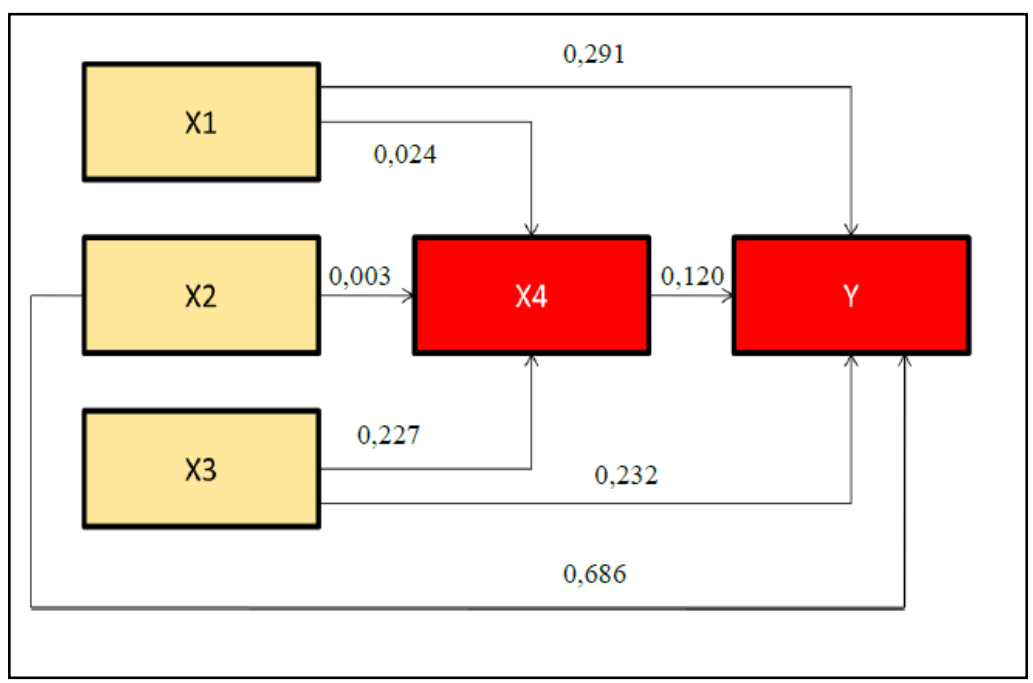

Sumber : Data primer diolah, 2016

Berdasarkan persamaan

tersebut di atas, dilakukan pengujian

Goodness of Fit model menggunakan koefisien determinasi total. Total keragaman data yang dapat dijelaskan oleh model diukur dengan rumus :

$$
\mathrm{R}_{\mathrm{m}}^{2}=1-\mathrm{P}_{\mathrm{e} 1}^{2} \mathrm{P}_{\mathrm{e} 2 \ldots . .}^{2} \mathrm{P}_{\text {ep }}^{2}
$$

Dimana:

$$
\begin{aligned}
& \mathrm{P}^{2}{ }_{\mathrm{e} 1}=1-\mathrm{R}^{2}{ }_{1} \\
& \mathrm{P}^{2}{ }_{\mathrm{e} 2}=1-\mathrm{R}^{2}{ }_{2} \\
& \mathrm{P}_{\text {ep }}^{2}=1-\mathrm{R}_{\mathrm{p}}^{2}
\end{aligned}
$$

Dimana $\mathrm{R}^{2}$ adalah $R$ square untuk persamaan 1 yaitu sebesar 
$0,052, \mathrm{R}_{2}^{2}$ adalah $R$ square untuk persamaan 2 yaitu sebesar 0,681 :

$$
\begin{aligned}
& \mathrm{P}_{\mathrm{e} 1}^{2}=1-0,052=0,948 \\
& \mathrm{P}_{\mathrm{e} 2}^{2}=1-0,681=0,319
\end{aligned}
$$

Sehingga diperoleh koefisien determinasi total adalah sebagai berikut:

$$
\mathrm{R}_{\mathrm{m}}^{2}=1-(0,948 \times 0,319)=
$$

0,6976 atau $69,76 \%$

1. Pengaruh Langsung dan Tidak Langsung
Pengaruh tidak langsung antara variabel independen terhadap variabel dependen melalui variabel intervening diperoleh dari hasil kali pengaruh langsung antara variabel dependen terhadap variabel intervening dan pengaruh langsung antara variabel intervening terhadap variabel independen (Riduwan dan

\begin{tabular}{|c|c|c|c|c|c|}
\hline Pengaruh & $\begin{array}{c}\text { Variabel } \\
\text { Independen }\end{array}$ & $\begin{array}{c}\text { Variabel } \\
\text { Intervening }\end{array}$ & $\begin{array}{l}\text { Variabel } \\
\text { Dependen }\end{array}$ & Path & Keterangan \\
\hline \multirow[t]{10}{*}{ Langsung } & $\mathrm{X} 1$ & - & $\mathrm{X} 4$ & 0,024 & $\begin{array}{c}\text { Tidak } \\
\text { Signifikan }\end{array}$ \\
\hline & $\mathrm{X} 2$ & - & $\mathrm{X} 4$ & 0,003 & $\begin{array}{c}\text { Tidak } \\
\text { Signifikan }\end{array}$ \\
\hline & X3 & - & $\mathrm{X} 4$ & 0,227 & $\begin{array}{c}\text { Tidak } \\
\text { Signifikan }\end{array}$ \\
\hline & $\mathrm{X} 1$ & - & $\mathrm{Y}$ & 0,291 & Signifikan \\
\hline & $\mathrm{X} 2$ & - & $\mathrm{Y}$ & 0,686 & Signifikan \\
\hline & X3 & - & $\mathrm{Y}$ & 0,232 & Signifikan \\
\hline & $\mathrm{X} 4$ & - & $\mathrm{Y}$ & 0,120 & $\begin{array}{c}\text { Tidak } \\
\text { Signifikan }\end{array}$ \\
\hline & $\mathrm{X} 1$ & $\mathrm{X} 4$ & $\mathrm{Y}$ & 0,003 & $\begin{array}{c}\text { Tidak } \\
\text { Signifikan }\end{array}$ \\
\hline & $\mathrm{X} 2$ & $\mathrm{X} 4$ & $\mathrm{Y}$ & 0,001 & $\begin{array}{c}\text { Tidak } \\
\text { Signifikan }\end{array}$ \\
\hline & $\mathrm{X} 3$ & $\mathrm{X} 4$ & $\mathrm{Y}$ & 0,027 & $\begin{array}{c}\text { Tidak } \\
\text { Signifikan }\end{array}$ \\
\hline
\end{tabular}
Kuncoro, 2011).

Tabel 4. Hasil Pengujian Hipotesis Pengaruh Langsung dan Tidak Langsung

Sumber : Data primer diolah, 2016

\section{Pengaruh Langsung}

a. Persamaan 1

- Pengaruh langsung antara X1 terhadap X4 diperoleh sebesar 0,024 dan merupakan pengaruh tidak signifikan.
- Pengaruh langsung antara X2 terhadap X4 diperoleh sebesar 0,003 dan merupakan pengaruh tidak signifikan.

- Pengaruh langsung antara X3 terhadap X4 diperoleh sebesar 0,227 
dan merupakan pengaruh tidak signifikan.

b. Persamaan 2

- Pengaruh langsung antara X1 terhadap Y diperoleh sebesar 0,291 dan merupakan pengaruh signifikan. Koefisien path yang bernilai positif menunjukkan bahwa semakin meningkat $\mathrm{X} 1$, maka akan terdapat kecenderungan bahwa $\mathrm{Y}$ akan semakin meningkat. Sebaliknya, apabila X1 menurun, maka akan terdapat kecenderungan bahwa $\mathrm{Y}$ akan semakin menurun.

- Pengaruh langsung antara X2 terhadap Y diperoleh sebesar 0,686 dan merupakan pengaruh signifikan. Koefisien path yang bernilai positif menunjukkan bahwa semakin meningkat $\mathrm{X} 2$, maka akan terdapat kecenderungan bahwa $\mathrm{Y}$ akan semakin meningkat. Sebaliknya, apabila X2 menurun, maka akan terdapat kecenderungan bahwa $\mathrm{Y}$ akan semakin menurun.

- Pengaruh langsung antara X3 terhadap Y diperoleh sebesar 0,232 dan merupakan pengaruh signifikan. Koefisien path yang bernilai positif menunjukkan bahwa semakin meningkat X3, maka akan terdapat

\section{Hipotesis}

Pengaruh

Tidak

\section{Langsung}

\section{Pengaruh terhadap Y melalui X4}

- Pengaruh tidak langsung antara X1 terhadap Y melalui X4 diperoleh dari hasil kali pengaruh langsung antara $\mathrm{X} 1$ terhadap $\mathrm{X} 4$ dan pengaruh langsung antara X4 terhadap $\mathrm{Y}$ sehingga diperoleh pengaruh tidak langsung sebesar $0,024 \times 0,120=$ 0,003 . Karena pengaruh langsung antara X1 terhadap X4 adalah tidak signifikan dan pengaruh langsung antara X4 terhadap Yadalah tidak signifikan, maka pengaruh tidak langsung X1 terhadap Y melalui X4 adalah tidak signifikan. Hal ini mengindikasikan bahwa X4 bukan merupakan variabel intervening (Perantara) yang baik sebagai variabel perantara antara variabel $\mathrm{X} 1$ terhadap Y. 
- Pengaruh tidak langsung antara X2 terhadap Y melalui X4 diperoleh dari hasil kali pengaruh langsung antara X2 terhadap X4 dan pengaruh langsung antara X4 terhadap $\mathrm{Y}$ sehingga diperoleh pengaruh tidak langsung sebesar $0,003 \times 0,120=$ 0,000. Karena pengaruh langsung antara X2 terhadap X4 adalah tidak signifikan dan pengaruh langsung antara X4 terhadap Yadalah tidak signifikan, maka pengaruh tidak langsung X2 terhadap Y melalui X4 adalah tidak signifikan. Hal ini mengindikasikan bahwa X4bukan merupakan variable intervening (Perantara) yang baik sebagai variabel perantara antara variabel X2 terhadap Y.

- Pengaruh tidak langsung antara X3 terhadap Y melalui X4 diperoleh dari hasil kali pengaruh langsung antara langsung antara X4 terhadap $\mathrm{Y}$ sehingga diperoleh pengaruh tidak langsung sebesar $0,227 \times 0,120=$ 0,027. Karena pengaruh langsung antara X3 terhadap X4 adalah tidak signifikan dan pengaruh langsung antara X4 terhadap Yadalah tidak signifikan, maka pengaruh tidak langsung X3 terhadap Y melalui X4 adalah tidak signifikan. Hal ini mengindikasikan bahwa X4bukan merupakan variabel intervening (Perantara) yang baik sebagai variabel perantara antara variabel X3 terhadap Y.

Penelitian ini menguji pengaruh pengeluaran pemerintah di bidang, kesehatan, pendidikan, dan infrastruktur terhadap peningkatan IPM dengan pendapatan per kapita sebagai variabel intervening di Kabupaten/Kota Provinsi Maluku. X3 terhadap X4 dan pengaruh

Tabel 5. Ringkasan Hasil Pengujian Hipotesis

\begin{tabular}{|c|l|c|}
\hline Kode & \multicolumn{1}{|c|}{ Hipotesis } & Hasil \\
\hline $\mathrm{H}_{1}$ & Kesehatan Berpengaruh signifikan terhadap Peningkatan IPM & Diterima \\
\hline $\mathrm{H}_{2}$ & Pendidikan Berpengaruh signifikan terhadap Peningkatan IPM & Diterima \\
\hline $\mathrm{H}_{3}$ & Infrastruktur Berpengaruh signifikan terhadap Peningkatan IPM & Diterima \\
\hline $\mathrm{H}_{4}$ & $\begin{array}{l}\text { Pendapatan per kapita tidak Berpengaruh signifikan terhadap } \\
\text { Peningkatan IPM }\end{array}$ & Ditolak \\
\hline
\end{tabular}

Sumber : Data primer diolah, 2016

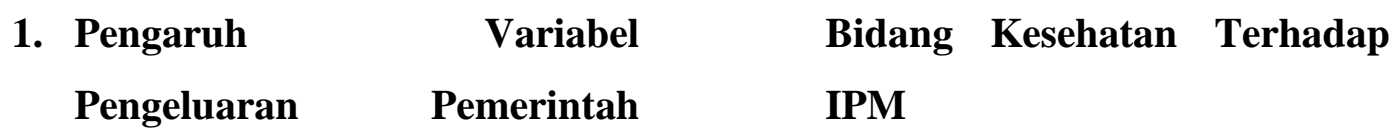


Hasil pengujian statistik Implikasi dari temuan ini menunjukkan bahwa besar pengaruh pengeluaran di bidang kesehatan terhadap peningkatan IPM sebesar 0,291, dimana pengaruh yang diperoleh bernilai positif. Nilai ini signifikan pada tingkat kesalahan 0,05 dengan signifikansi sebesar 0,001. Hal ini menunjukkan bahwa kesehatan berpengaruh signifikan terhadap peningkatan IPM sehingga hipotesis 1 diterima.

Hasil ini memperkuat temuan dari Rajkumar\& Swarop (2007), bahwa peningkatan 1 persen pengeluaran publik kesehatan per GDP menurunkan angka kematian dibawah 5 tahun sebesar 0,32 persen. Hal ini karena pengeluaran pemerintah telah efektif dalam membelanjakan beberapa alokasi bantuan kesehatan secara langsung maupun tidak langsung. Hasil penelitian ini juga dikuatkan oleh Jha, Biswal\& Biswal (2016) di India yang menemukan bahwa peran pengeluaran belanja kesehatan oleh pemerintah hampir dipastikan selalu berpengaruh terhadap kapasitas manusia yang lebih baik melalui saluran pengurangan kemiskinan. menekankan pentingnya alokasi anggaran kesehatan di setiap kenaikan anggaran dalam aspek fasilitas dan infrastruktur kesehatan di pedesaan. Razmi (2012) juga mengemukakan bahwa peningkatan kesehatan dapat meningkatkan produktivitas dan pasokan tenaga kerja. Produktivitas dan pasokan tenaga kerja dapat meningkatkan produktivitas dan pertumbuhan ekonomi.

Selain itu, Saha (2013), dalam penelitiannya mengenai implikasi tingkat kesehatan terhadap pertumbuhan produktivitas dan pertumbuhan ekonomi mengemukakan bahwa peningkatan pengeluaran kesehatan dapat mengurangi angka kematian dan meningkatkan harapan hidup. Saluran fiskal melalui belanja bidang kesehatan secara efektif berdampak terhadap pembangunan manusia. Dengan pengeluaran bidang kesehatan, orang lebih sehat dapat hidup lebih lama dan juga dapat bekerja lebihbaik dengan tingkat produksi yang lebih tinggi. Tingkat kesehatan yang lebih baik juga 
menunjang seseorang dapat mengakses tingkat pendidikan yang lebih tinggi. Menurut Razmi (2012), peningkatan pengeluaran kesehatan terutama untuk promosi kesehatan (pencegahan dan pelayanan kesehatan) sangat penting dalam meningkatkan kualitas manusia.

Berdasakan beberapa hasil penelitian di atas, maka pelayanan kesehatan gratis menjadi sangat penting dan wajib disediakan oleh pemerintah, khususnya dalam hal ini adalah Pemerintah Provinsi Maluku. Sarana kesehatan dan jaminan kesehatan harus dirancang sedemikian rupa oleh pemerintah melalui anggaran kesehatan yang memadai. Oleh karena itu, dukungan dana dari pemerintah pusat kepada pemerintah daerah sangat diperlukan.

Sejak tahun 2005, pemerintah pusat memberikan dukungan dana antara lain bantuan sosial berupa program Jaminan KesehatanMasyarakat (Jamkesmas) dan Jaminan Persalinan (Jampersal) yang baru dilaksanakan tahun 2011.Selain bantuan sosial, dana yang bersumber dari APBN adalah DAK (Dana Alokasi Khusus) bidang kesehatan. Pengeluaran pemerintah bidang kesehatan memiliki satu tujuan, yakni untuk meningkatkan derajat kesehatan masyarakat, yang dapat diukur dengan mengukur penurunan angka kematian bayi, penurunan angka kematian dibawah 5 tahun, dan peningkatan angka harapan hidup. Keseriusan pemerintah daerah Kabupaten/Kota Provinsi Maluku terhadap masalah kesehatan didaerahnya terlihat dalam pengalokasian anggaran. Rata-rata pengeluaran pemerintah bidang kesehatan di Kabupaten/Kota Maluku mengalokasikan anggaran sebesar 8,9\% dari total APBD. Hasil yang diperoleh dapat dilihat dari rata-rata angka harapan hidup yang kecenderungan mengalami perbaikan (meski tidak terlalu tinggi setiap tahunnya). Hal ini berarti bahwa kualitas kesehatan penduduk di Maluku telah mengalami peningkatan.

\section{Pengaruh Variabel Pengeluaran Pemerintah Bidang Pendidikan Terhadap IPM}

Hipotesis 2 menduga bahwa variabel pendidikan $\left(\mathrm{X}_{2}\right)$ mempunyai pengaruh yang signifikan terhadap 
variabel peningkatan IPM (Y). Hasil pengujian statistik dalam penelitian ini menunjukkan bahwa besar pengaruh pengeluaran di bidang pendidikan terhadap peningkatan IPM sebesar 0,686, dimana pengaruh yang diperoleh bernilai positif. Nilai ini signifikan pada tingkat kesalahan 0,05 dengan signifikansi sebesar 0,000. Hal ini menunjukkan bahwa pendidikan berpengaruh signifikan terhadap peningkatan IPM, sehingga hipotesis 2 diterima.

Hasil tersebut mendukung temuan dari Edeme (2014), yang meneliti di 20 negara bagian Nigeria pada tahun 1999-2012, bahwa pengeluaran publik untuk pendidikan memiliki efek signifikan pada pembangunan manusia. Efek pengeluaran bidang pendidikan ini menular ke bidang kesehatan, pertanian, pembanguan pedesaan dan energi, perlindungan lingkungan, perumahan dan sumber daya air. Penyediaan infrastruktur pendidikan dan peningkatan rata-rata tingkat pendidikan penduduk berimplikasi pada pendidikan tinggi dan meningkatnya kualitas SDM lokal dalam memanfaatkan sumber daya lokal di Nigeria.

Vierstraete (2012) menemukan bahwa alokasi belanja pendidikan yang dikelola dengan baik dapat menjadi faktor penting bagi pembangunan manusia karena adanya kepastian sumber daya manusia yang potensial. Hal ini didukung oleh Fattah (2012); dan Gupta, et.al (1998), yang menemukan bahwa investasi publik di sektor pendidikan dapat meningkatkan kualitas modal manusia yang akan meningkatkan produktivitas dan pada akhirnya dapat mengurangi kemiskinan. Temuan dari Baldacci et al, (2003) lebih menjelaskan secara spesifik, bahwa komposisi pengeluaran pendidikan antara pendidikan dasar dan menengah merupakan faktor penentu dari status pendidikan penduduk, terutama di negara-negara miskin. Kasus di negara-negara ini, khususnya investasi dalam pendidikan dasar dapat memiliki efek positif langsung pada hasil pendidikan melalui pengurangan buta huruf dan akses terhadap pelayanan sosial masyarakat. 
Hasil dari penelitianinisesuai dengan realisasi anggaran Kabupaten/Kota di Malukuyang memang memprioritaskan bidang pendidikan (meski belum dikatakan cukup optimal), dimana setiap tahunnya pemerintah daerah Kabupaten/Kota terus berupaya agar amanah konstitusi yaitu anggaran untuk pendidikan minimal $20 \%$ dapat terealisasi secara baik. Selain itu juga dari makin banyaknya realisasi program-program pendidikan seperti pendidikan gratis untuk Sekolah Dasar dan Sekolah Menengah Pertama. Provinsi Maluku juga mendapat dukungan dana dari pemerintah pusat seperti bantuan sosial berupa Program Bantuan Operasional Sekolah (BOS), yang telah berperan besar dalam percepatan pencapaian program wajib belajar 9 tahun. Sejak tahun 2009, pemerintah pusat telah memberi dukungan dana melalui program Bantuan Siswa Miskin (BSM). Program BSM merupakan Program Nasional yang bertujuan untuk menghilangkan halangan siswa miskin berpartisipasi untuk bersekolah dengan membantu memperoleh akses pelayanan pendidikan yang layak, mencegah putus sekolah, menarik siswa miskin untuk kembali bersekolah, membantu siswa memenuhi kebutuhan dalam kegiatan pembelajaran, mendukung program Wajib Belajar Pendidikan Dasar Sembilan Tahun (bahkan hingga tingkat menengah atas), serta membantu kelancaran program sekolah.Selain itu, dukungan dana dari pusat berupa juga berupa Dana Alokasi Khusus. Bantuan ini diarahkan untuk menunjang pelaksanaan program Wajib Belajar Pendidikan Dasar 9 tahun yang bermutu, yang diperuntukkan bagi SD, baik negeri maupun swasta, yang diprioritaskan pada daerah tertinggal, daerah terpencil, daerah perbatasan, daerah rawan bencana, dan daerah pesisir dan pulau-pulau kecil. Adanya pengaruh yang signifikan dan positif tersebut menunjukkan bahwa realisasi pengeluaran pemerintah bidang pendidikan Kabupaten/Kota Provinsi Maluku berpengaruh terhadap IPM terbukti dengan outcome yang dapat dilihat dari Angka Melek Huruf dan Rata-rata Lama Sekolah penduduk 
usia 15 tahun keatas yang mengalami peningkatan.

\section{Pengaruh Variabel Pengeluaran} Pemerintah Bidang Infrastruktur Terhadap IPM

Hipotesis 3 menduga bahwa variabel infrastruktur $\quad\left(\mathrm{X}_{3}\right)$ mempunyai pengaruh yang signifikan terhadap variabel peningkatan IPM (Y). Hasil pengujian statistik menunjukkan bahwa besar pengaruh pengeluaran di bidang infrastruktur terhadap peningkatan IPM sebesar 0,232, dimana pengaruh yang diperoleh bernilai positif. Nilai ini signifikan pada tingkat kesalahan 0,05 dengan signifikansi sebesar 0,007. Hal ini menunjukkan bahwa infrastruktur berpengaruh signifikan terhadap peningkatan IPM sehingga hipotesis 3 diterima.

Hasil temuan dari penelitian ini mendukung mayoritas penelitian sebelumnya, yang mengemukakan bahwa alokasi belanja infrastruktur berpengaruh signifikan terhadap tingkat IPM. Seperti yang dikemukakan oleh Rakhmawati\& Atikah (2015), bahwa belanja infrastruktur di Indonesia memberikan kontribusi terhadap peningkatan IPM. Hal ini karena alokasi belanja infrastruktur relatif besar dibandingkan dengan total pengeluaran. Diduga, belanja infrastruktur di Maluku berpengaruh signifikan terhadap IPM karena alokasinya relatif mencukupi.

Sapkota (2012) menemukan bahwa aksesbilitas infrastruktur yang lebih baik berkat alokasi anggaran yang lebih tinggi dapat mereduksi tingkat kemiskinan secara signifikan. Sapkota menemukan variabel infrastruktur seperti akses listrik dan air berdampak positif dan signifikan terhadap IPM. Ketersediaan aksesbilitas infrastruktur seperti listrik dapat meningkatkan pendapatan karena usaha masyarakat dan segala lini aktivitas lebih produktif, sehingga daya beli menjadi meningkat dan otomatis meningkatkan indeks IPM. Temuan ini sesuai dengan yang dikemukakan Kusharjanto\& Kim (2011), yang melakukan penelitian di 114 kabupaten Jawa dari tahun 2002 sampai tahun 2005. Infrastruktur yang dipertimbangkan dalam penelitian tersebut adalah listrik, air 
bersih, dan jalan. Hasilnya menunjukkan semua variabel ketersediaan infrastruktur mempunyai korelasi positif yang signifikan dengan IPM di Jawa dalam jangka panjang. Infrastruktur listrik memiliki pengaruh terbesar pada peningkatan IPM. Untuk setiap kenaikan $1 \%$ pada jumlah rumah tangga dengan listrik, IPM akan meningkat $0,2 \%$ dalam jangka panjang. Sementara itu, kenaikan $1 \%$ dalam penyediaan air bersih, peningkatan IPM sebesar $0,03 \%$. Implikasi utama dari penelitian ini adalah bahwa pembangunan infrastruktur layak menjadi perhatian lebih dari pemerintah.

Selain itu, keberadaan jalan merupakan urat nadi perekonomian, selain dapat membantu kelancaran mobilitas penduduk karena jalan mempunyai manfaat meningkatkan arus distribusi barang dan jasa produk yang dihasilkan untuk mencapai atau memasuki pasar yang lebih luas sehingga memungkinkan terpenuhinya kebutuhan dan manfaat yang lebih besar bagi para konsumen dan masyarakat pada umumnya. Selain itu, hal ini juga memungkinkan terjadinya pasar yang lebih luas dan konsentrasi produksi yang lebih besar dalam kaitan dengan usaha ekonomi skala besar. Efek dari meluasnya usaha ekonomi masyarakat secara otomatis dapat meningkatkan pendapatan masyarakat, sehingga perekonomian masyarakat dapat meningkat.

Pembangunan infrastruktur merupakan salah satu komponen penting yang akan menentukan keberhasilan pembangunan suatu bangsa. Selain berperan sebagai pendorong berkembangnya sektorsektor perekonomian, sektor infrastruktur pun juga dapat memberikan kontribusi yang cukup besar terhadap PDB. Infrastruktursebagai penentufungsiproduksi, mempunyaikontribusi terhadappertumbuhan ekonomi, memperbesar pasar, danberfungsimenurunkanhambatan perdagangan. Infrastruktur, khususnyainfrastruktur transportasi, memainkan peran kuncidalam pembangunan ekonomi. Hal ini sejalan dengan yang diungkapkan oleh Devarajan\& Swaroop (1993) 
yang mengungkapkan bahwa anggaran dalam bidang infrastruktur (jalan) diharapkan mampu meningkatkan akses masyarakat dalam bidang ekonomi sehingga akan terjadi efisiensi dan pada gilirannya akan meningkatkan konsumsi riil per kapita.

Maluku adalah provinsi yang memiliki jalan kabupaten/kota di pulau-pulau yang tersebar luas, namun ketersediaan infrastruktur di Maluku memang masih jauh dari yang diharapkan. Hal ini disebabkan oleh kecilnya investasi pemerintah daerah dalam infrastruktur yang masih dibawah 1 persen dari PDRB Maluku. Tren pertumbuhan belanja infrastruktur Kabupaten/Kota di Maluku tidak dapat mengimbangi pertumbuhan PDRB. Dengan kata lain, kemampuan pemerintah dalam memenuhi kebutuhan infrastruktur akan tertinggal oleh pertumbuhan ekonomi. Dengan tingkat belanja infrastruktur tersebut, sangat sulit bagi pemerintah daerah Kabupaten/Kota Provinsi Maluku untuk membiayai kebutuhan infrastruktur yang dapat menopang pertumbuhan ekonomi.

\section{Pengaruh Variabel Pendapatan Per Kapita Terhadap IPM}

Hipotesis 4 menduga bahwa variabel pendapatan per kapita $\left(\mathrm{X}_{4}\right)$ mempunyai pengaruh yang signifikan terhadap variabel peningkatan IPM (Y). Hasil pengujian statistik menunjukkan bahwa pendapatan per kapita terhadap peningkatan IPM adalah sebesar 0,120 dimana pengaruh yang diperoleh bernilai negatif. Nilai ini signifikan pada tingkat kesalahan 0,05 dengan signifikansi sebesar 0,150 . Hal ini menunjukkan bahwa pendapatan per kapita tidak berpengaruh signifikan terhadap peningkatan IPM sehingga hipotesis 4 ditolak.

Temuan dari penelitian ini bertolak belakang dengan beberapa penelitian terdahulu, seperti Ramirez, Ranis dan Stewart (1998), bahwa pertumbuhan ekonomi yang berdampak terhadap pendapatan per kapita seharusnya mempengaruhi pembangunan manusia, khususnya melalui aktivitas rumah tangga dan pemerintah serta peran organisasi masyarakat dan lembaga swadaya masyarakat. Aktivitas rumah tangga 
dalam

membelanjakan

pendapatannya cenderung untuk

kebutuhan-kebutuhan yang memiliki kontribusi langsung terhadap pembangunan manusia seperti makanan, pakaian, pendidikan dan kesehatan.

Penelitian ini juga kontra dengan apa yang disampaikan oleh Kosack dan Tobin (2006) dalam Anggraini dan Muta'ali (2013), bahwa melalui pertumbuhan ekonomi, pemerintah dapat menambah sumber daya untuk pembangunan manusia dengan meningkatkan belanja pendidikan dan kesehatan baik untuk fisik maupun non fisik. Peran pemerintah melalui kebijakan juga diperlukan untuk mengurangi kegagalan pasar yang cenderung menghambat investasi. Pengeluaran pemerintah melalui berbagai jenis belanja harus dapat memberi dukungan lebih pada pembangunan manusia.

Tetapi, yang perlu diketahui bahwa pertumbuhan ekonomi yang meningkat belum tentu dapat memeratakan tingkat pendapatan per kapita penduduknya, sehingga terjadigap dalam penyebaran pendapatan per kapita yang bisa menjadi penghambat untuk mengakses tingkat pendidikan dan kesehatan yang lebih baik. Meningkatnya pendapatan per kapita tidak selalu meningkatkan kemampuan (daya beli masyarakat) jika secara aksesbilitas masyarakat tersebut masih sulit. Meski PDRB per kapita dapat mempengaruhi capaian IPM, tetapi sifatnya tidak selalu signifikan. Hal ini karena PDRB per kapita menggambarkan rata-rata pendapatan yang diterima oleh setiap penduduk sebagai hasil dari seluruh produksi sektor-sektor ekonomi di suatu wilayah yang dapat mempengaruhi aktivitas daya beli. Tetapi, daya beli tidak selalu dapat disalurkan karena masih terdapat keterbatasan aksesbilitas terhadap konsumsi dan sumber daya demi meningkatkan kesejahteraan masyarakatnya. Keterbatasan aksesbilitas seperti yang terjadi di Provinsi Malukumasihmempersempit pilihan-pilihan masyarakat tidak hanya kesehatan dan pendidikan, tetapi juga pilihan-pilihan lain yang lebih berkualitas sehingga kualitas 
pembangunan manusianya belum tentu signifikan.

Rumah tangga dalam membelanjakan pendapatannya tergantung dari sejumlah faktor seperti tingkat dan distribusi pendapatan antar rumah tangga dan siapa yang mengontrol alokasi pengeluaran dalam rumah tangga. Penduduk miskin biasanya menghabiskan porsi pendapatannya lebih banyak untuk kebutuhan dasar seperti makanan dan minuman dibandingkan penduduk kaya. Dengan demikian, bagi penduduk miskin kebutuhan akan kesehatan dan pendidikan kurang diperhatikan, padahal kesehatan dan pendidikan merupakan faktor yang mempunyai pengaruh pada pembangunan manusia.

\section{Pengaruh Kesehatan,}

Pendidikan, dan Infrastruktur

Terhadap Peningkatan IPM

Secara Tidak Langsung Melalui

Pendapatan Per Kapita Sebagai

\section{Variabel Intervening}

Pada penelitian ini, dijelaskan bahwa variabel Kesehatan $\left(\mathrm{X}_{1}\right)$, Pendidikan $\left(\mathrm{X}_{2}\right)$, dan Infrastruktur $\left(\mathrm{X}_{3}\right)$ diduga mempunyai pengaruh terhadap variabel Peningkatan IPM (Y) secara tidak langsung melalui Pendapatan per kapita $\left(\mathrm{X}_{4}\right)$ sebagai variabel intervening.

a. Kesehatan dan Pendapatan Per Kapita

Penelitian ini menemukan bahwa kesehatan berpengaruh signifikan terhadap peningkatan IPMsecara langsung, namun variabel kesehatan tidak berpengaruh langsung terhadap pendapatan per kapita dan pendapatan per kapita tidak berpengaruh langsung terhadap peningkatan IPM. Dengan demikian, kesehatan tidak berpengaruh signifikan terhadap peningkatan IPMsecara tidak langsung melalui variabel intervening, yakni pendapatan per kapita. Temuan ini tidak sesuai dengan dugaan awal yang menjelaskan bahwa variabel belanja pemerintah sektor kesehatan akan berpengaruh langsung secara signifikan terhadap pendapatan per kapita.

Berdasarkan hasil pendalaman dari beberapa diskusi dengan Bappeda Provinsi Maluku, tidak berpengaruh secara signifikan pengeluaran pemerintah bidang 
kesehatan terhadap pendapatan per kapita di Provinsi Maluku disebabkan karena pemerintah belum mengalokasikan anggaran yang cukup banyak untuk sektor kesehatan. Rata-rata alokasi pengeluaran pemerintah bidang kesehatan di Kabupaten/Kota Maluku kurang dari $10 \%$ dari total APBD, padahal karakter wilayahnya sangat sulit dan akses kesehatan masih sangat kurang. Data dari BPS menunjukkan bahwa rata-rata angka harapan hidup memang kecenderungan mengalami perbaikan, tetapi tidak terlalu tinggi setiap tahunnya. Kondisi ini menandakan bahwa meski kualitas kesehatan penduduk di Maluku telah mengalami peningkatan, tetapi secara esensi masih belum optimal, sehingga implikasinya terhadap pendapatan per kapita sangat kecil.

b. Pendidikan dan Pendapatan Per Kapita

Berdasarkan hasil penelitian, diperoleh bahwa pendidikan berpengaruh signifikan terhadap peningkatan IPMsecara langsung, namun variabel pendidikan tidak berpengaruh langsung terhadap pendapatan per kapita dan pendapatan per kapita tidak berpengaruh langsung terhadap Peningkatan IPM. Oleh karena itu, diperoleh bahwa pendidikan tidak berpengaruh signifikan terhadap peningkatan IPMsecara tidak langsung melalui variabel intervening, yakni pendapatan per kapita.

Sama seperti kasus di bidang kesehatan, tidak adanya pengaruh signifikan antara alokasi pendidikan dan pendapatan per kapita karena alokasi dana untuk pendidikan masih kurang karena belum memenuhi amanah konstitusi sebesar 20\% (meski upaya peningkatan telah dilakukan). Padahal kebutuhan pendidikan masyarakat Provinsi Maluku yang rata-rata masih di wilayah yang mempunyai akses yang sulit membutuhkan tingkat aksesbilitas pendidikan yang sangat tinggi.

c. Infrastruktur dan Pendapatan Per Kapita

Penelitian ini menemukan bahwa infrastruktur berpengaruh signifikan terhadap peningkatan IPMsecara langsung, namun variabel 
infrastruktur tidak berpengaruh langsung terhadap pendapatan per kapita dan pendapatan per kapita tidak berpengaruh langsung terhadap peningkatan IPM. Dengan demikian, diperoleh bahwa infrastruktur tidak berpengaruh signifikan terhadap peningkatan IPMsecara tidak langsung melalui variabel intervening, yakni pendapatan per kapita.

Sama seperti kesehatan dan pendidikan, tidak berpengaruhnya alokasi dana infrastruktur terhadap pendapatan per kapita akibat alokasi dana yang sangat kurang, sementara infrastruktur dan hubungannya dengan peningkatan pendapatan masih terjadi time lag. Belum terkoneksinya infrastruktur perhubungan antar pulau turut mempengaruhi kondisi kemiskinan di Provinsi Maluku, sehingga kenaikan tingkat pendapatan belum bisa dirasakan oleh masyarakat. Akibat dari kecilnya anggaran infrastruktur di Maluku menyebabkan kualitas jalan menjadi buruk, terutama rasio panjang jalan. Persoalan ini tidak dapat mempercepat sirkulasi ekonomi, khususnya tata niaga perdagangan. Kelemahan ini berpotensi menghambat kemajuan masyarakat pada bidang sosial ekonomi dan budaya dari waktu ke waktu, baik sebagai jalur distribusi barang dan jasa, akses politik ke pusat-pusat kekuasaan, dan akses sosial budaya.

Beberapa hasil temuan di atas berimplikasi pada masing-masing bidang, baik pendidikan, kesehatan, infrastruktur, maupun pendapatan per kapita. Pertama, pada bidang pendidikan, ditemukan bahwa pengeluaran pemerintah bidang pendidikan mempunyai pengaruh lebih besar terhadap IPM. Kedepan, strategi alokasi anggaran pendidikan selayaknya lebih diarahkan pada peningkatan fasilitas penunjang pendidikan menengah, mengingat rata-rata lama sekolah penduduk Maluku masih sebesar 8,86 tahun, yang artinya rata-rata penduduk Maluku sudah dapat menyelesaikan sekolah dasar tetapi putus sekolah di pertengahan SMP. Selain itu, program peningkatan mutu pendidikan melalui peningkatan kapasitas pegawai dan tenaga pendidik harus lebih diperhatikan 
agar pelayanan pendidikan dapat lebih ditingkatkan.

Kedua, pada bidang kesehatan, masih diperlukan peran pemerintah dalam memberikan pelayanan kesehatan gratis terutama bagi rakyat miskin yang dituangkan dalam program upaya kesehatan masyarakat serta peningkatan sarana dan prasarana di puskesmas maupun puskesmas pembantu beserta jaringannya. Dalam bidang kesehatan, pemerintah telah berusaha meningkatkan pelayanan kesehatan dengan mengembangkan program jaminan kesehatan masyarakat (Jamkesmas). Selain program kesehatan yang bersifat kuratif, pengembangan program yang bersifat preventif seperti program promosi masyarakat perlu diberdayakan, agar masyarakat semakin memahami pola hidup sehat yang gilirannya akan meningkatkan kualitas kesehatan masyarakat. Keberpihakan dan keperdulian dalam bidang kesehatan ini perlu semakin diperluas secara merata ke seluruh wilayah Maluku yang notabene merupakan provinsi kepulauan, agar pencapaian peningkatan indeks pembangunan manusia lebih baik setiap tahunnya.

Ketiga, pada bidang infrastruktur, peningkatan pengeluaran pemerintah dalam hal ini adalah jalan, masih sangat diperlukan. Peningkatan alokasi anggaran infrastruktur khususnya jalan sangat penting untuk meningkatkan aksesibilitas penduduk dalam meningkatkan perekonomian lokal yang pada gilirannya dapat meningkatkan rata-rata tingkat pendapatan masyarakat. Untuk itu, ketersediaan jalan harus cukup serta kualitas jalan harus baik agar perekonomian menjadi lebih baik. Sebuah strategiyang komprehensif untukpenyediaan infrastruktur harus mencakup diversifikasi sumber daya keuangan dan meningkatkan partisipasisektor swasta. Selain itu, peningkatan kapasitas pemerintah daerah perlu diperkuat dengan merancang kebijakan yang memperkuat pembangunan infrastruktur. Ketersediaan infrastruktur di suatu daerah, khususnya di pulau-pulau Maluku yang notabene kaya akan potensi sumber daya alam dapat menarik 
investasi swasta dan publik, yang pada gilirannya dapat menyediakan dan menyerap tenaga kerja di daerah. Diharapkan hal ini dapat menghasilkan tingkat percepatan pembangunan ekonomi dan pembangunan manusia yang ditandai dengan meningkatnya pendapatan masyarakat.

Keempat, PDRB Per kapita merupakan hasil dari PDRB Maluku, yakni gambaran kemampuan suatu daerah mengelola sumber daya alam yang dimilikinya, sehingga besaran PDRB yang dihasilkan oleh masingmasing daerah sangat bergantung kepada potensi sumber daya alam dan faktor produksi daerah tersebut. Adanya keterbatasan dalam penyediaan faktor-faktor tersebut menyebabkan besaran PDRB bervariasi antar daerah. Oleh karena itu, pelu peningkatan pertumbuhan ekonomi dan pemerataan di Provinsi Maluku.

Bagaimanapun, pembangunan manusia semata-mata tidak hanya bertumpu pada pertumbuhan ekonomi, karena pertumbuhan ekonomi merupakan syarat perlu. Agar sejalan dengan pembangunan manusia, maka pertumbuhan ekonomi harus disertai dengan syarat cukup, yaitu pemerataan pembangunan, sehingga hasil pembangunan dapat dinikmati semua penduduk. PDRB per kapita dan IPM sebagai alat pengukuran kesejahteraan seharusnya selalu berjalan linier. Peningkatan PDRB seharusnya disertai peningkatan pemerataan pendapatan dan alokasi atas aktivitas yang meningkatkan kesejahteraan masyarakat, sehingga akan meningkatkan IPM.

\section{KESIMPULAN}

Berdasarkan hasil analisis pembahasan, maka kesimpulan dari penelitian ini adalah sebagai berikut:

Pengeluaran Pemerintah Provinsi Maluku bidang kesehatan selama periode 2009-2013 telah menunjukkan pengaruh positif dan signifikan terhadap IPM. Hasil ini sesuai dengan teori dan hipotesis yang mengatakan bahwa pengeluaran pemerintah bidang kesehatan akan meningkatkan kualitas sumberdaya manusianya. Rata-rata telah terjadi peningkatan realisasi pemerintah bidang kesehatan, yang selama lima tahun terakhir (2009-2013) rata-rata 
sebesar 8,9\%. Meski realisasi anggaran bidang kesehatan terbilang masih belum cukup tinggi, tetapi berhasil memperbaiki rata-rata angka harapan hidup yang artinya kualitas kesehatan penduduk di Maluku telah mengalami peningkatan.

Pengeluaran Pemerintah

Provinsi Maluku bidang pendidikan selama periode 2009-2013 telah menunjukkan pengaruh positif dan signifikan terhadap IPM. Hasil ini sesuai dengan teori dan hipotesis yang mengatakan bahwa pengeluaran pemerintah bidang pendidikan akan meningkatkan kualitas sumberdaya manusianya. Ada dua hal yang dapat menjelaskan dari hasil tersebut, yaitu: (i) realisasi anggaran bidang pendidikan Kabupaten/Kota di Provinsi Maluku sudah cukup, meskipun belum memenuhi amanah konstitusi, dimana selama lima tahun terakhir (2009-2013) rata-rata sudah sebesar $18,76 \%$; dan meningkatnya angka rata-rata lama sekolah dan angka melek huruf sebagai indikator indeks pendidikan.

1. Pengeluaran Pemerintah Provinsi Maluku bidang infrastruktur selama periode 2009-2013 telah menunjukkan pengaruh positif dan signifikan terhadap IPM. Hasil ini sesuai dengan teori dan hipotesis yang mengatakan bahwa pengeluaran pemerintah bidang infrastruktur akan meningkatkan kualitas sumberdaya manusianya. Hal ini disebabkan oleh tren investasi pemerintah dalam infrastruktur yang relatif sudah memadai, meski belum optimal.

2. Hasil statistik dalam penelitian ini menunjukkan bahwa pendapatan per kapita sebagai variabel intervening tidak berpengaruh signifikan terhadap peningkatan IPM. Hasil ini tidak sesuai dengan teori dan hipotesis yang menduga bahwa variabel pendapatan per kapita mempunyai pengaruh yang signifikan terhadap variabel peningkatan IPM. Kasus di Provinsi Maluku ini terjadi karena peningkatan daya beli penduduk Maluku tidak selalu dapat disalurkan karena masih terdapat keterbatasan aksesbilitas terhadap konsumsi dan sumber daya. Keterbatasan aksesbilitas mempersempit pilihanpilihan masyarakat tidak hanya kesehatan dan pendidikan, tetapi juga pilihan-pilihan yang lain sehingga 
kualitas pembangunan manusianya belum tentu signifikan.

\section{DAFTAR PUSTAKA}

Anggraini, Rinda Ayun., Luthfi Muta'ali. 2013. Pola Hubungan Pertumbuhan Ekonomi dan Pembangunan Manusia di Provinsi Jawa Timur Tahun 2007-2011, Jurnal Bumi Indonesia, Volume 2, Nomor 3, 233242.

Badrudin, Rudy,2011. Pengaruh pendapatan dan belanja daerah terhadap pembangunan manusia di propinsi daerah istimewa yogyakarta, Buletin Ekonomi Jurnal Manajemen, Akuntansi, dan Ekonomi Pembangunan, Vol. 9, No.1.

BPS Provinsi Maluku. 2008. Provinsi

Maluku Dalam Angka, Ekonomi dan Perdagangan.

2009.

Provinsi Maluku Dalam

Angka, Ekonomi dan

Perdagangan. 2010.

Provinsi Maluku Dalam
Angka, Ekonomi dan Perdagangan.

2011.

Provinsi Maluku Dalam

Angka, Ekonomi dan

Perdagangan.

Provinsi Maluku Dalam

Angka, Ekonomi dan Perdagangan.

Provinsi Maluku Dalam

Angka, Ekonomi dan Perdagangan.

Devarajan, S., and Swaroop. V., 1993. What do Government Buy? The composition of Public Spending and Economic Performance. Policy Research Waking Paper, The World Bank, WPS 1082.

Edeme, Richardson Kojo. 2014. Analyzing the effects of sectoral public spending on human development in nigeria: evidence from panel data. IOSR Journal of Humanities And Social Science (IOSR-JHSS), Vol. 19, Issue 9, pp. 01-13. 
Gupta, Sanjeev,. Clements,

Benedict,. and

Tiongson,Erwin,. 1998

Public Spending on Human

Development. Finance\&

Development.

Jha, Raghbendra; Biswal, Bagala\&

Biswal, Urvashi D. 2016. An

Empirical Analysis of The

Impact of Public Expenditure

on Education and Health on

Poverty in India States.

Australia South Asia

Research Centre: Canberra.

Kusharjanto, Heru; Kim, Donghun.

2011. Infrastructure and human development: the case of java, indonesia. Journal of The Asia Pacific Economy, Vol. 16, No. 1, pp. 111-124.

Rajkumar, Andrew Sunil; Swaroop, Vinaya. 2008. Public spending and outcomes: does governance matter?. Journal of Development Economics, Vol. 86, pp. 96-111.

Ramirez, Alejandro., Gustav Ranis, Frances Stewart. 1998.

Economic Growth and Human Capital, QEH Working Paper Series No.18.
Rakhmawati, Intan; Atikah, Siti. 2015. Do expenditures of education, health, and infrastructure improve human resources quality?. IJABER, Vol. 13, No. 7, pp. 47314742.

Razmi, Javad, Mohammad,. 2012.Investigating the effect of government health expenditure on HDI in iran,Journal of Knowledge Management, Economics and Information Technology.

Riduwan dan Kuncoro, Engkos Achmad. 2011. Cara Mudah Menggunakan dan Memaknai Path Analysis (Analisis Jalur). Penerbit ALFABETA Bandung.

Sapkota, Jeet Bahadur. 2012. Infrastructure Access and Human Development: CrossCountry Evidence and Post2015 Development Strategies. Faculty of Humanities and Social Sciences: University of Tsubuka.

UNDP, 1990. Human Development Report 1990. New York: Oxford University Press 
, 1995 . Human Development

Report 1995. New York:

Oxford University Press.

Vierstraete, Valerie. 2012.

Efficiency in human development: a data evelopment analysis. The

European Journal of Comparative Economics, Vol. 9, No. 3, pp. 425-443. 